\title{
References:
}

1. Davidenko, D. N., \& Pasichnichenko, V. A. (2003). Physical education as one of the parts of university education. Modern problems of physical education of students and the formation of a healthy lifestyle: materials of the republican scientific and practical work. Conf.-Mn.: MIESO.

2. Ermakov, S. S., \& Kriventsova, I. V. (2015). Prospect for the development of the primary discipline «Physically Vihovannya» from the main primary mortgages of Ukraine. Pedagogy and Psychology, no. 47, pp. 117-124.

3. Kuvshinchikov, I. N., Vlasov, G. V., \& Kobzar, A. N. (2011). Physical education as a means of forming a healthy lifestyle in student youth. Collection of scientific papers Sword. According to the materials of the international scientificpractical conference «Scientific research and their practical application». Odesa: Black Sea, T. 1, pp. 9-17.

\section{ARRAGEMENT OF DISTANT ENGLISH LEARNING IN PRIMARY SCHOOL: MECHANISMS OF IMPLEMENTATION}

\author{
Alina Vynokurova ${ }^{1}$ \\ Yuliia Masych $^{2}$
}

DOI: https://doi.org/10.30525/978-9934-588-52-5-5

The problem of optimization of the educational process, advanced development and implementation of distant learning attracts the attention of both domestic and foreign researchers (S. Honcharenko, I. Ziaziun, N. Nychkalo, I. Podlasnyi, etc.). In particular, didactic fundamentals of distant learning are represented in the works of V. Haluzynskyi, M. Makhmutov, and P. Iutsiavichene); psychological bases of the distance learning system have been considered by L. Vyhotskyi, P. Halperin, N. Talyzina, etc.). Traditionally, the subject matter of distant learning by educators from different countries is based on the following meanings: an educational process aimed at the use of modern information and communication technologies with distance in space and not involving face to face interaction [1]. In our research we will adhere to the relevant scientific views, the concept the education development in the context of the New Ukrainian School reforms, and we will consider the arrangement, methodology and implementation of the distant learning among primary school students [2].

\footnotetext{
${ }^{1}$ School № 12, Kremenchuk, Ukraine

2 School № 12, Kremenchuk, Ukraine
} 
During the global pandemic, the implementation of new innovative approaches to the interaction in the system of teacher-parent-student relationships has been preditermined to ensure safe conditions for exercising the right to education. In conditions of isolation, the learning process is complicated by psychologically difficult conditions, which sharply actualize the search of new opportunities for the realization of continuity of learning taking into account the individual characteristics of the educational activity subjects, including their digital skills. In this connection, there is a contradiction, on the one hand, the need for distance learning of students, on the other hand - there is the problem of putting new forms of remote work into practice. It should be noted that the main problem with the introduction of distant English learning is that its effectiveness depends not only on the competence of the teacher, technical arrangement of the process, students' readiness, but also on the psychological readiness of all parties to work in the new educational and cognitive network - i.e. the Internet.

Let's consider our experience of implementing the educational process of the English language teaching in the elementary school in the format of the distance learning, its mechanism of implementation. One of the online distant learning platforms is Google Classroom [4]. This resource has all the necessary opportunities for the teacher to arrange and structure the training materials, testing and correction of students' work, informative exchange, maintaining basic school documentation, mobility to be used on any device. Anyone who has a Gmail account can join this resource.

The teacher's primary purpose is to create the favourable conditions for the educational process with retaining all of its components. Before starting your work with Google Classroom you need to have some digital skills in working with online resources, to know the capabilities of the Google platform in general, to find and sort content corresponding to the students' age and their psychological features.

The following stages of the establishment of Google Classroom resource organizational work can be distinguished: 1 . The arrangement stage: creating a class, getting a code for participants, registration, tutorials to students, adding a note of the basic rules for working with the resource. 2. The methodical stage: creation of sections, topics with the addition of auxiliary accompanying materials to be used throughout the learning period by students, convenient orientation in the library of electronic class. 3. The educational stage: this is the main stage involving the direct development of lessons on the plan, the addition of video materials, audio, presentations, explanations, cards for oral and written work, support schemes, educational games on related online platforms and creative tasks. 4. The diagnostic correctional stage: this stage includes checking and 
analyzing the work of selected forms' efficiency and types of work, if necessary, improvement of problematic educational zones. 5 . The motivating phase: this stage has the accompanying nature and includes the main motivational lines of the learning process. In the current complicated crisis, this stage is not obligatory, though most depend on the psychological welfare of the family in which the child grows and the level of family selforganization. Therefore, the motivational stage in the distance learning conditions provides the child's learning activity and the possibility of its individual trajectory for development (own space, provision of technical resources, the existence of unresolved family conflicts, etc.). In this regard, we also note the intensive involvement of multimedia for all types of English distance learning courses that caused by the necessity of a complex formation of all kinds of speech skills, as well as linguistic and informationcommunicative competence of all subjects involving to the learning process.

Useful use of the Internet service becomes a designer to develop various tasks with multimedia content LearningApps.org and Quzizz. Kahoot, Hot Potatoes, Test $\mathrm{X}$ that are universal shells to create interactive test tasks using textual, graphical, audio and video information. Additional Google Form resources as a constructor provide the ability to create questionnaires, diagnostic works, online testing.

We describe in detail the empirical course and features of the implementation of the distance learning conducted on the basis of the Kremenchuk School Number 12 of Poltava region. In total, 79 students of primary school participated in the survey. At the initial stage of the research, some diagnostic work was carried out, which includes checking all activities on the subject, according to the criteria of visual perception, hearing, oral and written production [3]. The results of training on some criteria of avaluation of knowledge showed a moderate ownership of all activities (Table 1).

During the molding experiment, the training cycle in the number of 12 lessons was introduced for the distance learning form of study. The students being at the lessons in an electronic classroom received assignments which were aimed at the development of all activities on the subject. During the forming experiment, the control diagnostic work of the form the studied topic was studied only with the use of the distant learning form. The results of the experiment showed that in distance learning with the involvement of multimedia content, that students were more self-perceived material, processed the information obtained. Thus, it could be argued that the molding experiment in the conditions of the distant learning has positively influenced those activities that are based on visual-figurative thinking. The corresponding results are offended (Figure 1) with the appropriate reference [5]. The 
indicators of written production remained within the initial results of the existing level.

In this way distance learning today becomes fundamental and multifaceted. Based on the molding experiment, it can be argued that the English learning remote form helps to develop the basic competence of students which is initiated by the reforms of the New Ukrainian School, namely: the information-digital competence, the ability to learn throughout life, the foreign language communication, the environmental literacy and Healthy life and cultural literacy. Obvious advantages allow to distant forms of education to root in modern vision and prospects for the development of modern Ukrainian education.

Table 1

\section{Comparative chart of English language activities by some criteria in class 2 students during the forming experiment}

\begin{tabular}{|c|c|c|c|}
\hline \multicolumn{2}{|c|}{ Section 1 } & \multicolumn{2}{c|}{ Section 2 } \\
\hline Activity & \% & Activity & \% \\
\hline Reading & $55 \%$ & Reading & $57 \%$ \\
\hline Listening & $48 \%$ & Listening & $50 \%$ \\
\hline Speaking & $49 \%$ & Speaking & $49 \%$ \\
\hline Writing & $53 \%$ & Writing & $52 \%$ \\
\hline
\end{tabular}

四 Insights

Median

$11 / 12$ points

Total points distribution

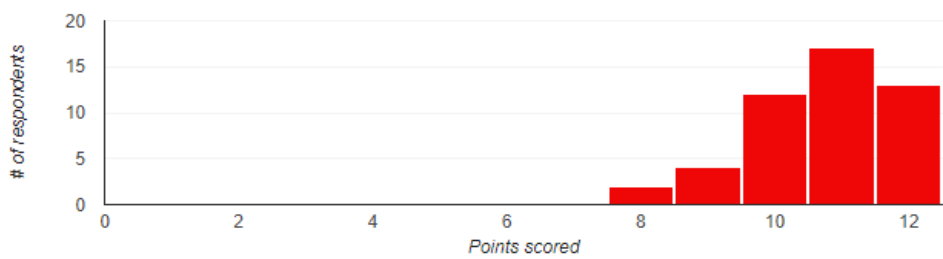

Figure 1. Screenshot of the comparison table of the experiment 


\section{References:}

1. United States Dastance Learning Association. Retrieved from: htpp://www.usdla.org (accessed 15 April 2020).

2. Kontseptsiia rozvytku osvity Ukrainy na period 2015-2025 rr. Retrieved from: http://www.irf.ua/knowledgebase/news/koncepciya_rozvytku_osvity_na_period_2015 2025rr/ (accessed 17 April 2020).

3. Dejneka, L. (ed.) (2019). Metodyka vykladannja inozemnoji movy v pochatkovij shkoli [Methods of teaching a foreign language in primary school]. Skhidnojevrop. nac. un-t im. Lesi Ukrajinky, Biblioteka. Lucjk, 159 nazv. (in Ukrainian)

4. Retrieved from: https://classroom.google.com/u/0/c/NTQ1NjkxMTI3NTda (accessed 15 April 2020).

5. Retrieved from: https://docs.google.com/forms/d/1GI1NDdnvtzOcEaw6Ppxg ATMxFS6FWinBCQO4N-nMd_Y/edit\#responses (accessed 15 April 2020).

\section{USING OF INTELLECTUAL MAPS AT THE LESSONS OF MATHEMATICS AT GENERAL SECONDARY EDUCATION INSTITUTIONS}

\section{Alina Klimishyna ${ }^{1}$ \\ DOI: https://doi.org/10.30525/978-9934-588-52-5-6}

An important task of every teacher is to teach a child to think. Every year, as part of the reform and modernization of the educational system, the amount of educational material increases and it is clear that it is becoming increasingly difficult for pupils to remember and operate with such a large amount of information. Therefore, when explaining new material to the teacher, it is necessary to develop in pupils the ability to analyze, synthesize, evaluate, summarize, as well as highlight the main and related concepts.

It is worth noting that scientists who have studied the problems of neurophysiology have made an important discovery about the functional asymmetry of the hemispheres of the human brain, which can not be ignored during training. It is proved that the right hemisphere is «responsible» for figurative thinking, for holistic perception, for the perception of spatial forms, and the left - for language, logic, work with signs. In the vast majority of people, the right hemisphere is included in the work first when acquainted with new information. Therefore, for the successful development of knowledge it is advisable to strengthen the visual component of the material, which is presented as a counterweight (in some cases) or a necessary

\footnotetext{
${ }^{1}$ General Education School of I-III degrees № 1, Ivaniv, Ukraine
} 